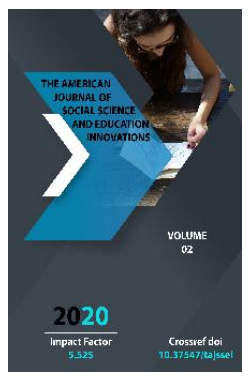

\title{
Factors For The Development Of Writing Skills Of Law Students In A Modular System
}

\author{
Zulfiya Pulatova \\ Specialized Branch of Tashkent State University Of Law, Senior Lecturer Of The Department \\ of General Education Disciplines, Uzbekistan
}

Journal Website:

http://usajournalshub.c

om/index,php/tajssei

Copyright: Original

content from this work

may be used under the

terms of the creative

commons attributes

4.0 licence.

\section{ABSTRACT}

Teaching and learning law consists not only of learning all theoretical rules and skills, but also in the acquisition of communicative skills. Accordingly, the purpose of this article is to demonstrate how to promote writing skills in higher education especially law students in modular system. Furthermore, factor of communicative competence is a term that is necessary and much more practical in teaching and learning law direction than in other areas of competence.

If we look at the historical background of this term, communicative skills is a term in linguistics that refers to the grammatical knowledge of syntax, morphology, phonology and the like of a language user, as well as to social knowledge of how and how.

\section{KEYWORDS}

Modular system, writing skills, higher education, law students, feedback, assessment, learning process, curriculum.

\section{INTRODUCTION}

The modular system, which is one of the modern forms of education, is becoming increasingly popular due to its dynamics and high level of efficiency. Advantages and disadvantages of the education system in relation to its deeper penetration is going to be discussed. Many higher education institutions around the world today are an 
effective route of the educational process, as well as a system in which this process is supported by all the requirements of modular educational technologies. "The specificity of modular education is determined by such criteria as its purpose and content, forms and methods, areas of interaction between teacher and student." ${ }^{1}$ The module is a unitbased database of integrated and logically structured programs in a particular subject area, which includes logical, didactic, independent sections of lectures and practical courses, educational-technological maps, literature, control blocks and reporting forms.

The module highlights the purpose and requirements of state educational standards, taking into account the characteristics of the higher education institution, the problems of professional and practical strengthening. It should be noted that, unlike traditional education, the role of the teacher in the use of modular learning technologies changes as an element of the pedagogical system. That is, "by giving students the opportunity to independently determine the goals, content, forms, methods and means of learning activities at the same time, the teacher's responsibility for the learning process and outcome is not reduced." ${ }^{2}$ At the same time, one of the most important factors of the modular system is that the teacher and the student become equal participants in the learning process due to their interest in

\footnotetext{
${ }^{1}$ Juceviciene P. A. Theory and practice of modular training. [Text] / P. A. Savicheva. - Kaunas: Shviesa, 1989. - 227 p.

${ }^{2}$ Vorontsova T. A. Elementary stylistics: teaching and learning resources.ljevsk Udmurt University, 2009. $130 \mathrm{p}$.
}

achieving concrete results. ${ }^{3}$ In this case, it is important that the teacher and students work together to choose the best way of teaching for each student.

The teacher organizes feedback during the lesson. As a result, the teacher will be able to see the level of preparation of students, the appropriateness of the chosen form, means, etc., the quality and pace of learning by students of educational units, modules or an entire module program, based on which to correct mistakes in the educational process. "The teacher creates conditions for students to self-manage, and thus determines the optimal level of their participation in the process of education management."4

It can be seen that modular education, in addition to allowing to demonstrate its hightech nature due to its unique features, also provides solutions to many problems of teaching science direction. The block structure of the module covers the main stages of education and makes it easier for students and teachers to understand and implement in the learning process, as well as to share more information.

In the world, special attention is paid to research on the modular system of teaching foreign languages. Given that the object of our study was not focused on the module system, we decided to limit our coverage to the concept of module and its functions. The

\footnotetext{
${ }^{3}$ Galskova N. D. Modern methods of teaching foreign languages. Moscow: ARKTI-Glossa, 2000. 165 p.

${ }^{4}$ Giraldo F. the impact of the professional development program on the class of English language teachers performance. Profile issues of professional development of teachers in 2014. No. 16 (1). Pp. 6376.
} 
concept of "module" is one of the new terms of the modern education system, which is part of the structure of educational programs in which several disciplines, courses and sections of science are studied. ${ }^{5}$ The module is often used as a synonym for a particular subject, a cycle of a curriculum in a subject, a course syllabus.

The essence of the modular form of education is characterized primarily by the student's mastery of the subject, as well as the teacher's control over the learning process, the organization of the learning process, as well as the promotion, coordination and control of student activities. Today, the module performs the following functions in education:

- The "working" part of the curriculum;

- Base for creating new curricula;

- The basis for improving professional development programs.

The educational process organized using the module is carried out in accordance with the approved curricula. The structure of the curriculum, on the other hand, includes a number of modules, and the implementation of this volume is reflected in the credits (no more than 60 credits per academic year can be mastered). Each module will have its own configurable learning elements depending on the didactic objectives. The learning element of the module will consist of a goal, a list of materials, manuals, and a test of the acquired knowledge.

\footnotetext{
${ }^{5}$ Solovova E. N. Methods of teaching foreign languages: basic course of lectures: a guide for students of pedagogical universities and teachers. 2nd ed. Moscow: Prosveshchenie, 2003. 239 p.
}

Typically, each model consists of 5-8 learning elements: introduction, learning objectives, key problems (cases) of the element, textual information, exercises, summaries, bibliographic list, glossaries. The purpose of the module program is to organize and implement an educational process aimed at individualism, improving the efficiency and quality of training, as well as the formation of universal-professional competencies. ${ }^{6}$

Students should master them independently and achieve the goals set in the process of working on the module. Curriculum modules should be structured to achieve the stated pedagogical goals and be clear enough to inform students. Assessment is carried out through a rating system of knowledge assessment. The modular system of education is implemented in the format of ECTS European credit transfer system ${ }^{7}$ (Bologna system $)^{8}$, which is based on the entire volume of training carried out through loans. The basic terms of the module are:

- Module (part of the educational process, direction of science);

- Assessment rating system (assessment of points on the results of current classes, modules, semester control and other forms of educational activities);

\footnotetext{
${ }^{6}$ The Cube H A practical guide to evaluating English language learners. At the University of Michigan Click. 2013, 231 p.

${ }^{7}$ European Credit Transfer and Accumulation System (ECTS). https://ec.europa.eu/education/resourcesand-tools/european-credit-transfer-and-accumulationsystem-ects_en

${ }^{8}$ The Bologna Process and the European Higher Education Area. https://ec.europa.eu/education/policies/highereducation/bologna-process-and-european-highereducation-area_en
} 
- Credit is a unit of measurement of educational work, audience and independent work; One ECTS credit has 36 academic hours, and a student must take 60 credits in one academic year; forms of work on credit: practical and laboratory work, lectures, seminars, independent work, consultations, examinations and qualifying works. ${ }^{9}$

Now, when talking about the factors of development of writing skills of students of legal direction in a direct modular system, it should be noted that the development of writing skills in the study of foreign languages occurs through the study of written speech of students.

In the process of reviewing written speech, it is necessary to determine its place in the education system and its relationship with other types of educational activities. According to some experts, "it is necessary to first form in students the ability to understand and speak, and then to form reading and writing."10 The essence of this concept is that the student also first learns to understand and speak in their native language and then learns to write. This is also manifested as a natural law.

One of our first tasks is to find an answer to the question of how oral and written speech are related to each other. One of the founders

9 Coombe Ch. A Practical Guide to Assessing English Language Learners. The University of Michigan Press. 2013, 231 p.

${ }^{10}$ Vasilyeva M. M., Sinyavskaya E. V. Methods of teaching foreign languages abroad. Moscow: Progress, 1967. 425 p. of the theory of writing. B. de Courtenay ${ }^{11}$ distinguished two different forms of speech activity: auditory-based pronunciation and visual writing. ${ }^{12}$ However, acknowledging this, the scholar does not equally contradict them, and considers that the former (pronunciation based on hearing) arises and is thought to be independent of the latter (review).

Human language is the language of sounds produced by auditory perception and human articulation. Therefore, while oral speech is the basis of human interaction through language, written speech in turn reinforces oral speech in a unique way. "Oral speech can exist and be in constant motion, but written speech cannot exist without oral speech, or without thinking."133 Therefore, before developing writing skills in students, it is very important to develop and strengthen oral speech as much as possible, to improve their intellectual enrichment.

It should also be noted that oral speech not only can affect the formation of written skills in students, but also written speech is a factor that lays the foundation for the development and fluency of oral speech. Written speech can be said to be a very important and necessary form of speech activity, but it is also not necessary from the pedagogical point of view to exaggerate its role and artificially increase its importance. "Writing skills can be

\footnotetext{
${ }^{11}$ Ivan Alexandrovich Baudouin de Courtenay. https://ru.wikipedia.org/wiki.

12 Baudouin de Courtenay I. A. Selected works on General linguistics, Moscow: Publishing house of The Academy of Sciences of the USSR, 1963. 384 p.

13 Giraldo F. The impact of a professional development program on English language teachers' classroom performance. PROFILE Issues in Teachers’ Professional Development 2014. №16(1). Pp. 63-76.
} 
assessed as a complex stage in the development of language skills in students. Because it is really a complex form that includes oral speech."14 In turn, writing skills are characterized by complex skills (different knowledge) and somewhat complex psychological structures. According to scholars, it is possible to prove that written communication is separate and independent, and they are based on the following:

1. Students can achieve any level of written skills without having to fully master any foreign language orally; the main reason for this is that they use writing and teaching as well as authentic materials in the process of learning foreign languages, and this is sufficient for mastering foreign languages. It is well known that among students, there are many who can read and write words in a foreign language well, but it is difficult to speak and understand. The main reason for this is that students have been engaged in writing since the initial learning process, and only then, they have learned to hear and receive sounds. ${ }^{15}$

2. Suggestions on the secondary coded nature of the written language are rejected, if such re-coding is mandatory, then the following events should be observed: would have required large psychological costs. "This doesn't happen

\footnotetext{
${ }^{14}$ Posvyaschena V. Y., Modular teaching foreign languages in non-linguistic University [Manuscript] / author. Diss.... candidate of pedagogical Sciences 13.00.02 / V. Y. Pasvyanskene; Vilnius, 1989.

15 Miller A. Criteria for effective assessment in project-based learning. Retrieved from http://www.edutopia. org/blog/effective-assessmentproject-based-learning-andrew-miller (date requests:01.12.2017).
}

because the speed of writing doesn't lag behind the speed of speech for some psychological reason, but the movement of the hand is a bit slower than the movement of the speaking organs."16

Thus, writing skill differs from sound language functions in that it manifests itself as a separate type of activity. Written speech is a graphical representation of oral speech in which the psychophysiological mechanisms of oral speech are preserved in the form of written speech. One of the main factors in the formation of students' writing skills is the development of their listening and comprehension skills. The first task of the educator should be to understand the word or sound he / she hears, to study it with the help of thinking and to translate it into writing with timely understanding of its functional aspects, in other words, to describe and describe what he hears in writing. ${ }^{17}$

It is self-evident that the differences between oral and written skills are of a psychological nature rather than a linguistic one. Researchers have highlighted the following differences in the text: ${ }^{18}$

1. The written text provided to the students should not be changed. The text can be read

\footnotetext{
${ }^{16}$ Shubin E. P. Language communication and teaching foreign languages. Moscow: Prosveshchenie, 1972. 180 p.

${ }^{17}$ Henning G. Twenty common testing mistakes for EFL teachers to avoid. English Teaching Forum 2012. №3. Pp. 33-40. Retrieved from http://americanenglish.state.gov/files/ae/resource_file S/50_3_8_henning.pdf

${ }^{18}$ Solovova E. N. Methods of teaching foreign languages: basic course of lectures: a guide for students of pedagogical universities and teachers. 2nd ed. Moscow: Prosveshchenie, 2003. 239 p.
} 
over and over again and its content remains unchanged. The person reading the text can choose the strategy and speed of reading, reread it, and even correct the meaning of unfamiliar words in the dictionary.

2. The written text should contain relatively short and detailed information. The author of the written text works autonomously, does not always know his audience, and the speaker at the same time is in direct contact with him, has instant feedback and in the process corrects his text.

3. Because the written text is expressed in a different structure and composition, it should be borne in mind that the author has the opportunity to correct it several times during the writing period, as well as before reaching the reader in the final version.

4. It takes a lot of time for students to write a writing text that will serve to develop their writing skills. However, sometimes we want to get that information from a written source faster than we hear certain information.

5. Written texts place strict requirements for maintaining the normality of language.

6. Students need to learn to write and pay more attention to it in order to have writing skills, to work hard on themselves. However, it should never be forgotten that the written text is aimed at serving the formation of students' various writing skills. ${ }^{19}$

It should also be noted that if we take a deep and serious approach to the analysis of the factors of formation and development of writing skills in students, first, there is a correlation between writing and reading, as mentioned above. The difference between

19 Wiggins G. Defining assessment. Available at http://www.edutopia.org/grant-wiggins-assessment (date requests:18.12.2017). them is that writing is often based on the coding method as well, while reading is based on implementation without codes. "In this case, it is often the writing skills that help to develop reading skills. That is why writing is an effective form of activity that allows to preserve language and phonetic knowledge, serves as a reliable tool of thinking, encourages speaking, listening and reading in a foreign language". ${ }^{20}$

In addition, the formation of writing skills in law students, the development of communicative competencies in them have been studied by scientists, including wellknown linguists and psychologists AR Luriya, Yu.Yu. Kovaleva, Yu.I. Semenova and others. possible. It should be noted that they have done a lot of work on the formation of writing skills in students, which includes many advanced ideas.

A scholar named L.S. Vygotsky, interpreted written speech as "the most verbal, clear, common form of speech conveyed using intonation and words that directly explain the situation in oral speech". ${ }^{21}$ Therefore, in order to learn foreign languages effectively and successfully, it is necessary to form writing skills and abilities in students. Undoubtedly, notes reinforce the students 'oral and verbal form skills, providing the basis for the language's effective mastery of the graphic system. The process of improving the skills of

\footnotetext{
${ }^{20}$ Posvyaschena V. Y., Modular teaching foreign languages in non-linguistic University [Manuscript] / author. Diss.... candidate of pedagogical Sciences 13.00.02 / V. Y. Pasvyanskene; Vilnius, 1989.

${ }^{21}$ Ushakova S. V. on approaches to teaching creative writing in a foreign language in a modern secondary school // Foreign languages at school. 2010. No. 9. P. 61.
} 
writing and mastering the technique in a foreign language in English has a positive educational effect on the strengthening of their memory and will of students. ${ }^{22}$

Now the factors that develop writing skills in students, mainly law students, as a direct logical direction of the topic is the next issue.

The main factors for the development of writing skills in a modular system for students majoring in law are:

1. Students who need to develop writing skills should, first of all, form knowledge to the extent that they can explain the internal content of the text to the reader, to express their reaction to the object, to develop different answer options; ${ }^{23}$

2. Due to the fact that writing skills do not have additional means of expression in oral or non-verbal skills (gestures, gestures, thinking, smiling, expressing bad moods), students need to develop very subtle and professional practices to show such inner experiences. increase access to various artistic or documentary works, sources; ${ }^{24}$

3. Underline the text in the development of writing skills, taking into account the fact that future lawyers work with various crimes, cases, realities in criminal, administrative, civil and other fields,

\footnotetext{
${ }^{22}$ Halskov N. D. Modern methods of teaching foreign languages: a Handbook for teachers. 3rd ed., reprint. and add. M.: ARKTI, 2004. 162 p.

${ }^{23}$ Leontiev A. A. General methodology of teaching foreign languages. Moscow: Russian language, 1991. $360 \mathrm{p}$

${ }^{24}$ Semenova Yu.I. Assessment techniques in the course «Theory of Language Acquisition». Actual problems of modern foreign language education: Collection of articles No. 5. Kursk: Kursk state University, 2017.
}

review various contracts, court decisions and other legal documents, to prepare for such cases as putting different marks, enclosing quotation marks, calling for clarification of suspicious cases with the help of question marks, separating them with parentheses, constantly improving stylistic training in this area;

4. Also to form and develop the ability to make full use of the advanced, perfected, perfect grammatical means of the language, to control the strict adherence to the articulation of details in a clear and fluent manner, in order to fully cover a reality in English;

Due to the high role of psychological factors in the evaluation of any legal process, the motives, the presence of motivating factors, law students should study in depth not only legal terms, but also psychological terms, the expression of realities, the specifics of their description. in addition, they will be able to study in depth the topics of their writing, their reflection in documents, and develop the skills to represent them in legal documents;

In-depth study of the use of some figurative words, expressions, descriptive realities in English in official, legal documents, mastering their synonymous, phraseological aspects, continuous improvement of pedagogical methods to acquire skills to apply in practice;

On the basis of their specialties and official duties, to study in depth the subjects, norms, terms of international law, the constant study of international court proceedings and the expressions used in them, the constant introduction and analysis of the practice of studying documents reflecting the processes; 
organization of seminars, round tables, colloquiums, conferences;

Students' writing skills with the participation of students, specialists, government agencies, non-governmental organizations, law enforcement agencies, lawyers, practitioners, international journalists, depending on the characteristics of the legal direction, the constant changes and development factors in the world of law today. various trainings, open lessons, talks, press conferences, the organization of classrooms and mobile classes, the involvement of not only English teachers, but also legal teachers with a deep knowledge of English in such important events, and so on.

\section{CONCLUSION}

All of the above tasks can be assessed as key factors in the formation and development of English writing skills in students studying law. Indeed, today the deep study of English by lawyers is reflected not only in the domestic life of the country, but also as a factor in improving the economic, political, foreign policy, investment climate, raising the image of the international arena.

In conclusion, the introduction of a modular system in today's education system, through which, using various advanced pedagogical technologies, along with the development of the education system, to show the mistakes and shortcomings, to improve the writing skills of students studying law, improving activity, communication skills remains one of the biggest requirements.

\section{REFERENCES}

1. Juceviciene P. A. Theory and practice of modular training. [Text] / P. A. Savicheva. - Kaunas: Shviesa, 1989. $227 \mathrm{p}$.

2. Vorontsova T. A. Elementary stylistics: teaching and learning resources.ljevsk Udmurt University, 2009. $130 \mathrm{p}$.

3. Galskova N. D. Modern methods of teaching foreign languages. Moscow: ARKTI-Glossa, 2000. 165 p.

4. Giraldo F. The impact of the professional development program on the class of English language teachers' performance. Profile issues of professional development of teachers in 2014. No. 16 (1). Pp. 63-76.

5. Solovova E. N. Methods of teaching foreign languages: basic course of lectures: a guide for students of pedagogical universities and teachers. 2nd ed. Moscow: Prosveshchenie, 2003. $239 \mathrm{p}$.

6. The Cube $\mathrm{H}$ A practical guide to evaluating English language learners. At the University of Michigan Click. 2013, 231 p.

7. European Credit Transfer and Accumulation System (ECTS). https://ec.europa.eu/education/resour ces-and-tools/european-credittransfer-and-accumulation-systemects_en

8. The Bologna Process and the European Higher Education Area. https://ec.europa.eu/education/policie s/higher-education/bologna-processand-european-higher-educationarea_en 
9. Coombe Ch. A Practical Guide to Assessing English Language Learners. The University of Michigan Press. 2013, $231 \mathrm{p}$.

10. Vasilyeva M. M., Sinyavskaya E. V. Methods of teaching foreign languages abroad. Moscow: Progress, 1967. $425 \mathrm{p}$.

11. Ivan Alexandrovich Baudouin de Courtenay. https://ru.wikipedia.org/wiki.

12. Baudouin de Courtenay I. A. Selected works on General linguistics, Moscow: Publishing house of The Academy of Sciences of the USSR, 1963. $384 \mathrm{p}$.

13. Giraldo F. The impact of a professional development program on English language teachers' classroom performance. PROFILE Issues in Teachers' Professional Development 2014. №16(1). Pp. 63-76.

14. Posvyaschena V. Y., Modular teaching foreign languages in non-linguistic University [Manuscript] / author. Diss.... candidate of pedagogical Sciences 13.00.02 / V. Y. Pasvyanskene; Vilnius, 1989. 